\title{
Immunocytochemical studies of pancreatic acinar cells in normal and streptozotocin-induced diabetic rats
}

\author{
S. Grégoire and M. Bendayan \\ Department of Anatomy, Faculty of Medicine, University of Montreal, Montreal, Quebec, Canada
}

\begin{abstract}
Summary. Amylase and chymotrypsinogen in pancreatic tissue from normal and diabetic rats were revealed by immunocytochemistry and analyzed biochemically. In acinar cells of control animals, both enzymes were localized with high resolution in the rough endoplasmic reticulum, Golgi apparatus, immature and mature secretory granules. Quantitative evaluations of the intensities of labelings have demonstrated, for both enzymes, the presence of an increasing gradient which followed precisely their secretory pathway. This gradient reflects the normal processing of both proteins through secretion. In streptozotocin-induced diabetic animals, labeling for amylase in acinar cells was markedly reduced (remaining about $11 \%$ of the normal values). The gradient along the secretory pathway was abolished, indicating an alteration in the
\end{abstract}

processing and secretion of amylase. On the other hand, labeling for chymotrypsinogen was significantly increased (to $170 \% p<0.0005$ ), and its processing remained normal. In insulin-treated diabetic animals, immunolabeling for amylase was restored and the gradient re-established, indicating a normalization of the secretion. Labeling for chymotrypsinogen was reduced towards normal values. These results were found to be in agreement with those obtained by biochemical approaches and demonstrate that, in the diabetic condition, secretion of amylase is selectively impaired.

Key words: Pancreas, acinar cell, amylase, chymotrypsinogen, immunocytochemistry, diabetes.

the study of protein secretion [20], and was previously applied in the investigation of the pancreatic function [21]. Following the same line, we have undertaken the investigation of the pancreatic acinar tissue of streptozotocin-induced hyperglycaemic rats applying the quantitative protein A-gold immunocytochemical technique [22]. Two enzymes, amylase and chymotrypsinogen, the secretion of which appears to be altered in the diabetic condition, were analyzed. Furthermore, the effect of insulin on the processing of amylase and chymotrypsinogen by acinar cells from streptozotocin-treated rats was also evaluated.

\section{Materials and methods}

An experimental chronic hyperglycaemic state was induced in Sprague-Dawley male rats by intravenous injection of streptozotocin. Fifty animals of about $100 \mathrm{~g}$ body wt. were fasted overnight. Forty of them received a single injection $(0.2 \mathrm{ml})$ of $50 \mathrm{mg} / \mathrm{kg}$ body wt. of streptozotocin (Boehringer Mannheim, Quebec, Canada) diluted in $10 \mathrm{mmol} / 1$ sodium citrate at $\mathrm{pH}$ 4.5. Ten control animals received the same volume of the sodium citrate solution. The animals were kept in individual cages, had free access to food (Purina Chow River) and 
water. Urine samples were collected and analyzed weekly for the presence of glucose, proteins and ketone bodies and for their $\mathrm{pH}$ (reagent $\mathrm{N}$-multistix, Ames, Ontario, Canada). Among the animals receiving the streptozotocin injection, 30 of them demonstrated significant glucosuria 24 to $48 \mathrm{~h}$ after the injection. Glucose in urine remained positive along the entire experiment. They also showed strong ketonuria, and urine $\mathrm{pH}$ of about 5 . Four animals receiving the streptozotocin injection, but not demonstrating glucosuria, were used as another group of controls. All animals were kept for three months and were then killed by decapitation after a blow on the head. Five streptozotocininjected animals demonstrating strong glucosuria were treated with a daily injection of insulin (NPH, Connaught Laboratories, Ontario, Canada; $8 \mathrm{U} /$ day per animal) for a period of 10 days. This treatment eliminated the presence of glucose in urine. These animals received their tenth injection $2 \mathrm{~h}$ before killing. Five streptozotocin-hyperglycaemic animals and five control rats were fasted overnight before killing. Blood was collected only at time of death, and serum glucose levels were determined by the glucose oxidase method.

\section{Immunocytochemistry}

Small fragments of the splenic part of the pancreas were fixed by immersion with $0.1 \mathrm{~mol} / 1$ phosphate buffered $1 \%$ glutaraldehyde for $2 \mathrm{~h}$ at room temperature and were then washed in the same buffer. The tissues were, or were not, postfixed with phosphate buffered $1 \%$ osmium tetroxide for $60 \mathrm{~min}$ at $4{ }^{\circ} \mathrm{C}$. Embedding was performed in Epon according to standard procedures. Thin sections were cut, mounted on nickel grids and processed for immunocytochemistry.

Two different antibodies, one directed against amylase and the other against chymotrypsinogen, were used in this study. These antibodies were those raised in guinea pig, characterized and used previously for the light [9] and electron microscopic [21] localization of these two same secretory proteins in rat pancreatic tissue. In the present study, they were applied with the protein A-gold technique [22] for the localization of the corresponding protein in pancreatic tissues from the different groups of animals. The protein A-gold technique was applied according to procedures already described using gold particles of $14 \mathrm{~nm}$ in diameter [22]. Briefly, the tissue sections mounted on grids were incubated for $5 \mathrm{~min}$ on a drop of $0.01 \mathrm{~mol} / 1$ phosphate buffer saline pH7.3 (PBS) containing 1\% ovalbumin, transferred without rinsing onto a drop of the diluted antibody $(1: 50$ for amylase and $1: 10$ for chymotrypsinogen) and incubated for $2 \mathrm{~h}$ at room temperature. The grids were then rinsed to remove excess unbound antibodies, transferred on a drop of PBS containing 1\% ovalbumin for $5 \mathrm{~min}$ and finally incubated on a drop of the protein A-gold complex for $1 \mathrm{~h}$ at room temperature. After this incubation, the grids were thoroughly washed with PBS, rinsed in distilled water and dried. The tissue sections were stained with uranyl acetate and lead citrate before examination in the electron microscope.

In the case of osmium-tetroxide postfixed tissues, the thin sections were first incubated on a saturated aqueous solution of sodium metaperiodate for $1 \mathrm{~h}$ at room temperature [22]. The grids were then carefully rinsed with distilled water, transferred on a drop of PBS containing $1 \%$ ovalbumin, and then processed according to the above described protocol.

The specificity of the immunolabeling obtained with the protein A-gold technique was assessed through several control experiments as described in detail previously [22]: (1) incubation with the protein Agold complex alone; (2) incubation with antigen-adsorbed antiserum followed by the protein A-gold complex; (3) incubation with the antiserum followed by unlabeled protein $A$ and protein A-gold complex.

The quantitative evaluation of labelings was performed as described previously [22]. Twenty-four micrographs of different acinar cells were taken for each animal from all control and experimental groups at the initial magnification of $X 6,000$; they were then enlarged to a final magnification of X 48,000. A modular system for quantitative digital image analysis (MOP-3, Carl Zeiss Inc., Quebec, Canada) was used for these evaluations.

\section{Biochemistry}

For the biochemical determination of amylase and chymotrypsinogen, the tissue fragments were immersed in the appropriate Triton buffer [23] and homogenized. Amylase and chymotrypsinogen were analyzed according to the procedures described by Bernfeld [24] and Hummel [25] respectively. DNA was extracted according to Mainz et al. [26] and measured by the method of Volkin and Cohn [27] using calf thymus DNA as a standard.

\section{Statistical analysis}

Statistical evaluations of the morphological and biochemical results were performed using Student's t-test for paired samples.

\section{Results}

When compared to the control (buffer-injected) normoglycaemic animals, the streptozotocin-induced hyperglycaemic rats displayed a moderate weight gain $(210 \pm 20 \mathrm{~g}$ versus $410 \pm 20 \mathrm{~g}$ for the controls). Blood glucose levels were significantly enhanced in the streptozotocin diabetic animals $(34.19 \pm 2.78 \mathrm{mmol} / 1$ versus $6.49 \pm 0.50 \mathrm{mmol} / \mathrm{l}$ for the controls $p<0.0001$ ). The hyperglycaemic state remained very significant after overnight fasting $(31.58 \pm 1.28 \mathrm{mmol} / 1 p<0.0001)$.

Amylase and chymotrypsinogen were revealed by immunocytochemistry in the different compartments of the acinar cells. In cells from control animals, a labeling for both enzymes was found over the rough endoplasmic reticulum, the Golgi apparatus, the immature and mature secretory granules; the latter presented the highest intensity of labeling (Figs. 1a, b). A positive reaction was also found over the content of the acinar lumen. Very few gold particles were present over the nucleus and the mitochondria. The intensities of labeling obtained for amylase were superior to those obtained for chymotrypsinogen. These results were confirmed by the quantitative evaluations (Tables 1,2 ) which further revealed, for each enzyme, the presence of an increasing gradient in the intensities of labelings along the rough endoplasmic reticulum-Golgi-granules secretory pathway. The intensities of labeling observed for the control animals after overnight fasting were similar to those observed for the normally-fed animals (Tables 1,2 ). The specificity of the results was assessed through numerous experiments. Indeed, when the labeling was performed with the antibodies pre-adsorbed with their corresponding antigens (either anti-amylase plus amylase or antichymotrypsinogen plus chymotrypsinogen), very few gold particles were found over the acinar cells. However, when the adsorption was performed with the opposite antigen (either anti-amylase plus chymotrypsinogen or anti-chymotrypsinogen plus amylase), the labeling remained unchanged. Very few gold particles were found when the antibody step was omitted or when protein $\mathrm{A}$ was used prior to the protein A-gold complex. All these results are in agreement with those published previously on normal rat pancreatic tissue [20-22]. 

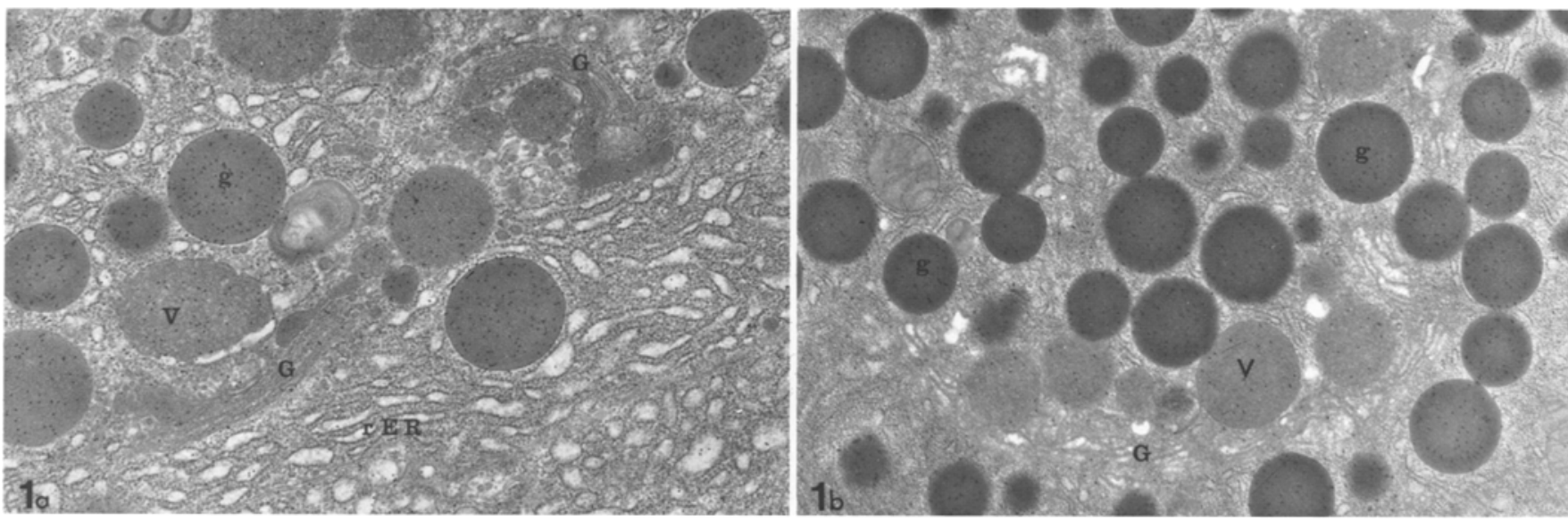

Fig. $1 \mathbf{a}$ and $\mathbf{b}$. Electron micrographs of pancreatic acinar cells from a normal rat. Localization of a amylase and $\mathbf{b}$ chymotrypsinogen by the protein A-gold technique. The labeling by gold particles is present at the level of the different cellular compartments: the rough endoplasmic reticulum (rER), the Golgi apparatus (G), the condensing vacuoles (V) and the secretory granules (g). (1\% glutaraldehyde - $1 \%$ osmium tetroxide; Epon; sodium metaperiodate; anti-amylase or anti-chymotrypsinogen/protein A-gold). a X 13,500; b X 10,500

Table 1. Density of labeling obtained for amylase at the level of the rat pancreatic acinar cells

\begin{tabular}{|c|c|c|c|c|c|c|}
\hline Cellular compartments & $\begin{array}{l}\text { Control rats } \\
\text { (overnight } \\
\text { fasting) } \\
n=5\end{array}$ & $\begin{array}{l}\text { Hyperglycaemic } \\
\text { rats (overnight } \\
\text { fasting) } \\
n=5\end{array}$ & 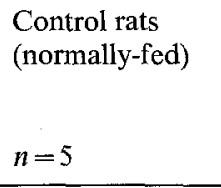 & $\begin{array}{l}\text { Hyperglycaemic } \\
\text { rats } \\
\text { (normally-fed) } \\
n=5\end{array}$ & $\begin{array}{l}\text { Hyperglycaemic } \\
\text { rats (plus insulin) } \\
n=5\end{array}$ & $\begin{array}{l}\text { Normoglycae- } \\
\text { mic rats (inject- } \\
\text { ed with strepto- } \\
\text { zotocin) } \\
n=4\end{array}$ \\
\hline $\begin{array}{l}\text { Rough endoplasmic } \\
\text { reticulum }\end{array}$ & $5.76 \pm 0.26$ & $5.09 \pm 0.21 *$ & $14.53 \pm 1.40^{* * *}$ & $7.59 \pm 0.37 * *$ & $23.00 \pm 1.26$ & $6.88 \pm 0.34$ \\
\hline Zymogen granules & $118.48 \pm 3.34^{+}$ & $11.73 \pm 0.45^{+++}$ & $102.99 \pm 4.31$ & $12.67 \pm 0.48^{+++}$ & $139.72 \pm 4.28$ & $111.39 \pm 2.75^{+}$ \\
\hline
\end{tabular}

Values identified with similar symbols are not significantly different from one another; otherwise, values are significantly different $(p<0.0005)$. $\mathbf{n}=$ number of animals. Twenty-four cells were evaluated for each animal. Anti-amylase antibody/protein A-gold expressed as gold particles per $\mu \mathrm{m}^{2}$; mean values $\pm \mathrm{SEM}$

Table 2. Density of labeling obtained for chymotrypsinogen at the level of the rat pancreatic acinar cells

\begin{tabular}{|c|c|c|c|c|c|c|}
\hline Cellular compartments & $\begin{array}{l}\text { Control rats } \\
\text { (overnight } \\
\text { fasting) } \\
n=5\end{array}$ & $\begin{array}{l}\text { Hyperglycaemic } \\
\text { rats (overnight } \\
\text { fasting) } \\
n=5\end{array}$ & $\begin{array}{l}\text { Control rats } \\
\text { (normally-fed) } \\
n=5\end{array}$ & $\begin{array}{l}\text { Hyperglycaemic } \\
\text { rats } \\
\text { (normally-fed) } \\
n=5\end{array}$ & $\begin{array}{l}\text { Hyperglycaemic } \\
\text { rats (plus insulin) } \\
n=5\end{array}$ & $\begin{array}{l}\text { Normoglycae- } \\
\text { mic rats } \\
\text { (injected with } \\
\text { streptozotocin) } \\
n=4\end{array}$ \\
\hline $\begin{array}{l}\text { Rough endoplasmic } \\
\text { reticulum }\end{array}$ & $8.35 \pm 0.31 *$ & $11.86 \pm 0.29 * *$ & $12.89 \pm 0.43^{* * *}$ & $13.23 \pm 0.89^{* * *}$ & $13.44 \pm 0.52 * * *$ & $6.50 \pm 0.30$ \\
\hline Golgi apparatus & $8.88 \pm 0.37^{*}$ & $12.13 \pm 0.44^{* *}$ & $14.82 \pm 0.55$ & $23.88 \pm 1.48^{++}$ & $20.04 \pm 0.90$ & $10.94 \pm 1.02^{* *}$ \\
\hline Condensing vacuoles & $17.22 \pm 1.34$ & $25.54 \pm 1.90^{++}$ & $33.15 \pm 1.42$ & $54.45 \pm 2.35^{+++}$ & $43.08 \pm 1.90$ & $24.76 \pm 1.30^{++}$ \\
\hline Zymogen granules & $50.70 \pm 1.77^{+++}$ & $85.76 \pm 2.28^{+}$ & $67.47 \pm 1.65$ & $112.51 \pm 3.85$ & $85.72 \pm 1.83^{+}$ & $59.10 \pm 2.51$ \\
\hline
\end{tabular}

Values identified with similar symbols are not significantly different from one another; otherwise, values are significantly different $(p<0.0005)$. $n=$ number of animals. Twenty-four cells were evaluated for each animal. Anti-chymotrypsinogen antibody/protein A-gold expressed as gold particles per $\mu \mathrm{m}^{2}$; mean values $\pm \mathrm{SEM}$

In pancreatic acinar cells of streptozotocin-induced hyperglycaemic animals, the labeling for amylase was markedly reduced. Indeed, only few gold particles were present over the different cellular compartments involved in secretion, the rough endoplasmic reticulum, the Golgi apparatus and the secretory granules
(Fig.2a). Background staining remained very low. These results were confirmed by the quantitative evaluations, with amylase labeling obtained under diabetic condition about $11 \%$ of that found in controls (Table 1 ). In addition, quantification demonstrated that there was no major concentration of the immunolabeling from 

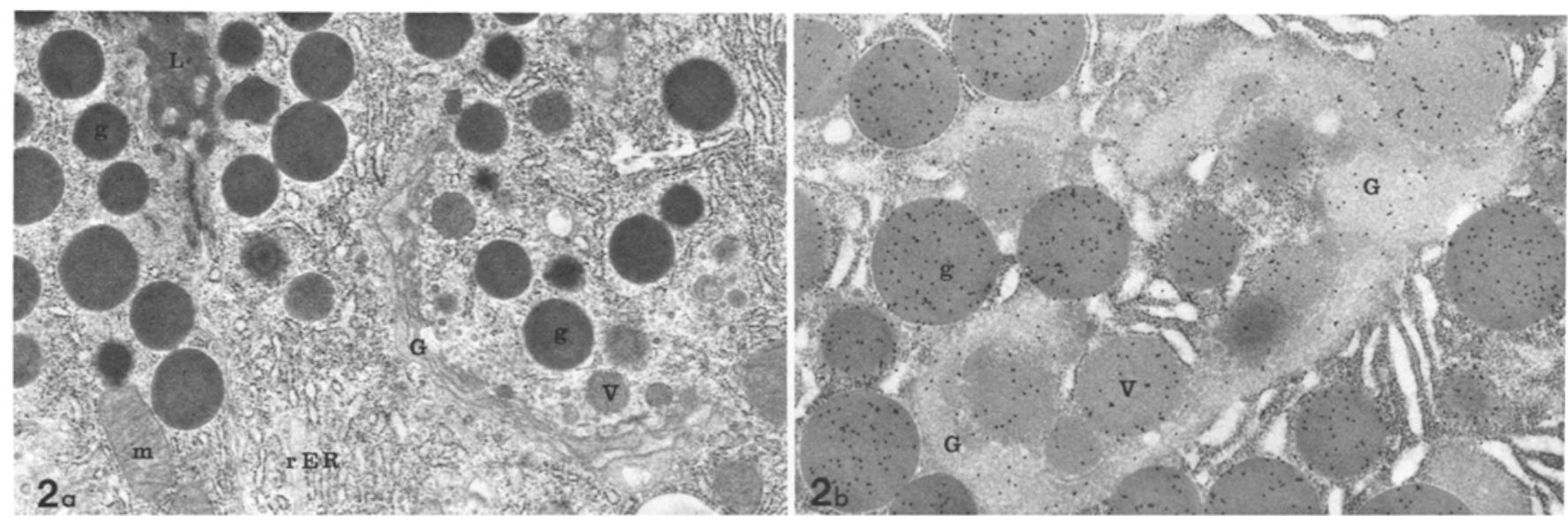

Fig. 2. a Electron micrograph of pancreatic acinar cell from a streptozotocin-induced diabetic rat (glycaemia: $37.52 \mathrm{mmol} / 1$ ). Localization of amylase by the protein A-gold technique. The labeling by gold particles over the different cellular compartments is very low. rER: rough endoplasmic reticulum; G: Golgi apparatus; V: condensing vacuole; $g$ : secretory granule; L: acinar lumen; m: mitochondria. (1\% glutaraldehyde 1\% osmium tetroxide; Epon; sodium metaperiodate; anti-amylase/protein A-gold). X 11,500. b Electron micrograph of pancreatic acinar cell from streptozotocin-induced diabetic rat (glycaemia: $37.52 \mathrm{mmol} / \mathrm{l}$ ). Localization of chymotrypsinogen by the protein A-gold technique. The labeling by gold particles is intense and present over the different cellular compartments. Golgi apparatus (G); condensing vacuole (V); secretory granules (g). (1\% glutaraldehyde; Epon; anti-chymotrypsinogen/protein A-gold). X 15,500

Table 3. Results of the biochemical assays for amylase and chymotrypsinogen in rat pancreatic tissues

\begin{tabular}{lcl}
\hline & $\begin{array}{l}\text { Amylase } \\
\text { units/mg DNA }\end{array}$ & $\begin{array}{l}\text { Chymotrypsino- } \\
\text { gen units/mg } \\
\text { DNA }\end{array}$ \\
\hline $\begin{array}{l}\text { Control rats (overnight } \\
\text { fasting) } \\
(n=5)\end{array}$ & $3184.82 \pm 45.78^{*}$ & $145.77 \pm 29.84$ \\
$\begin{array}{l}\text { Hyperglycaemic rats } \\
\text { (overnight fasting) } \\
(n=5)\end{array}$ & $14.01 \pm 3.52^{+}$ & $271.80 \pm 23.14$ \\
$\begin{array}{l}\text { Control rats } \\
\text { (normally-fed) } \\
(n=5)\end{array}$ & $3313.39 \pm 755.51^{*}$ & $90.14 \pm 8.11^{*}$ \\
$\begin{array}{l}\text { Hyperglycaemic rats } \\
(\text { normally-fed) } \\
(n=5)\end{array}$ & $10.53 \pm 2.70^{+}$ & $197.37 \pm 17.20^{+}$ \\
$\begin{array}{l}\text { Hyperglycaemic rats (plus } \\
\text { insulin) } \\
(n=5)\end{array}$ & $3934.64 \pm 754.89^{*}$ & $238.10 \pm 31.82^{+}$ \\
$\begin{array}{l}\text { Normoglycaemic rats } \\
\text { (injected with } \\
\text { streptozotocin } \\
(n=4)\end{array}$ & $2675.93 \pm 269.24^{*}$ & $76.88 \pm 12.70^{*}$ \\
\hline
\end{tabular}

In each vertical column, values identified with similar symbols are not significantly different from one another; otherwise, values are significantly different $(p<0.0005), n=$ number of animals. Mean values \pm SEM

one compartment to the other. On the other hand, in these same cells, the immunolabeling obtained for chymotrypsinogen was intense (Fig. 2b). Indeed, numerous gold particles were present over the rough endoplasmic reticulum, the Golgi apparatus and the secretory granules. These results were confirmed by quantitative evaluations (Table 2), which demonstrated that the intensities of labeling obtained in acinar cells from diabetic animals were higher (about 170\%) than those found for the control animals $(p<0.0005)$. Furthermore, the increasing gradient in the intensity of this labeling was present along the secretory pathway. The results obtained on the pancreatic acinar cells from overnight fasted hyperglycaemic rats were similar to those of normally-fed hyperglycaemic animals; labeling for amylase was drastically reduced while that for chymotrypsinogen was increased (Tables 1 and 2).

Acinar cells from streptozotocin-injected normoglycaemic animals (glycaemia: $6.22 \pm 0.44 \mathrm{mmol} / 1$ ) demonstrated labelings for amylase and chymotrypsinogen which were qualitatively identical to, and quantitatively in the range of, the results found for control animals in this (Tables 1 and 2) and previous studies [20,21].

Results obtained on acinar cells from insulin-treated diabetic animals showed intense labelings for amylase and chymotrypsinogen. The quantitative evaluations (Tables 1 and 2) confirmed these observations and demonstrated that the intensities of labeling obtained for both enzymes were even higher (about 130\%) than those found in control animals. Furthermore, the gradient of immunolabeling was present for both amylase and chymotrypsinogen.

The biochemical analysis of amylase and chymotrypsinogen contents in the tissues of the different groups of animals are presented in Table 3 . The results obtained from the amylase assays demonstrated a drastic decrease of the enzyme in tissues from streptozotocin-induced diabetic animals while no difference was found between the control, the diabetic insulin-treated and the streptozotocin-injected normoglycaemic animals. No difference was also observed between normally-fed animals and those fasted overnight. The results 
obtained from the chymotrypsinogen assays demonstrated an increase in the activity of the enzyme in the diabetic and in the hyperglycaemic insulin-treated animals when compared to the controls. No difference was observed between the control and the streptozotocin-injected normoglycaemic rats. Activities of chymotrypsinogen were higher in tissues of overnight fasted animals than in those of normally-fed animals (Table 3 ).

\section{Discussion}

In this study, we have investigated by quantitative immunocytochemistry the distribution of two secretory proteins in the exocrine pancreas of normal and streptozotocin-induced diabetic rats. In the normal animal, amylase and chymotrypsinogen were revealed with high resolution in the different cellular compartments involved in protein secretion. The quantitative evaluation has demonstrated the presence of a gradient in the intensity of labeling which increases along the rough endoplasmic reticulum-Golgi-granule secretory pathway. These results are in total agreement with those reported previously $[20,21]$. Results obtained on tissues from diabetic animals, on the other hand, have demonstrated the presence of major alterations in the secretory activity of the acinar cells. Indeed, the labeling obtained for amylase was found to be drastically decreased while that for chymotrypsinogen was significantly increased. Similar observations were made on normally fed and on overnight fasted animals, indicating that the intake of food by diabetic animals did not stimulate amylase secretion. These results are supported by our biochemical analysis, and are in agreement with previous reports demonstrating a depletion of pancreatic amylase under diabetic conditions $[15,16,18,19,28,29]$. According to the results obtained, these alterations do not seem to correspond to a direct influence of streptozotocin, since pancreatic tissue of animals having received the drug but not having developed an hyperglycaemic state shows no major modification in amylase secretion. Furthermore, acinar cells from spontaneous hyperglycaemic BB (Bio-Breeding, Ottawa, Canada) rats are also depleted of amylase (unpublished observations). The quantitative evaluations performed on amylase and chymotrypsinogen immunolabelings over the different compartments of the acinar cells in diabetic animals have revealed the presence of an increasing gradient in labeling intensities only for the chymotrypsinogen. This gradient was previously interpreted as reflecting the increment of protein concentration [20]; however, it can also result from the increment in antigenicity which may occur along with protein maturation. Nevertheless, the modification in this gradient observed for the remaining low levels of amylase in diabetic animals reflects alterations in the processing of this protein. Such a decrease in amylase content under diabetic condition was related to a decrease in amylase synthesis as dem- onstrated by changes in amylase mRNA levels [17]. The alteration seems to be dependent on insulin levels, which appear to play a key role in the processing of amylase [2,3]. Insulin has been shown to regulate amylase mRNA [17], and our results have confirmed that treatment of the diabetic animals with insulin restores amylase immunolabeling in the acinar cells with the reappearance of the increasing gradient along the secretory pathway. Insulin treatment also affected chymotrypsinogen, since its labeling was decreased toward normal values. Therefore, insulin appears to restore the normal secretory activity of the acinar cells. However, it is difficult to establish in a definite way if the alterations observed are directly related to the insulin deficiency or are the result of the hyperglycaemic state. Indeed, regulation of amylase secretion by circulating blood glucose levels has also been suggested [2, 3, 29]. Nevertheless, the lack of amylase under diabetic conditions may well represent an adaptation process through which the animal reduces glucose absorption.

Acknowledgments. The authors acknowledge Drs. J.Morisset and E. Rasio for their help in the biochemical evaluations of the pancreatic enzymes and the blood samples. The excellent technical assistance of Ms. D. Gingras, C. Venne and J. Léveille is also acknowledged. This investigation was supported by grant MT-7284 from the Medical Research Council of Canada. M.B. is recipient of a Scientist Award from the MRC. This work was presented in an abstract form at the $36^{\text {th }}$ Annual Meeting of the American Histochemical Society in Crystal City, Virginia, USA, in 1985 (J Histochem Cytochem 34: 118, 1986).

\section{References}

1. Henderson JR (1969) Why are the islets of Langerhans? The Lancet 2: $469-470$

2. Williams JA and Goldfine ID (1985) The insulin pancreatic acinar axis. Diabetes 34: $980-986$

3. Williams JA and Goldfine ID (1986) The insulin acinar relationship. In: Go VLW, Brooks FP, Dimagno EP, Gardner JD, Lebenthal $E$ and Scheele GA (eds) The exocrine pancreas: biology, pathobiology and diseases. Raven Press, New York, pp 347-360

4. Fujita T (1973) Insulo-acinar portal system in the horse pancreas. Arch Histol Jap 35: 161-171

5. Wharton GK (1932) The blood supply of the pancreas, with special reference to that of the islands of Langerhans. Anat Rec 53: $55-81$

6. Hellmann B, Wallgren A and Peterson B (1962) Cytological characteristics of the exocrine pancreatic cells with regards to their position in relation to the islets of Langerhans. Acta Endocrinol (Copenh) 39:465-473

7. Kramer MF and Tan HT (1970) The peri-insular acini of the pancreas of the rat. Z Zellforsch 86: $163-170$

8. Malaisse-Lagae F, Ravazzola M, Robberecht P, Vandermeers A, Malaisse WJ and Orci L (1975) Exocrine pancreas evidence for topographic partition of secretory function. Science 190: 795-797

9. Bendayan $M$ and Ito $S$ (1979) Immunohistochemical localization of exocrine enzymes in normal rat pancreas. J Histochem Cytochem 27: 1029-1034

10. Bendayan M (1985) Morphometrical and immunocytochemical characterization of peri-insular and tele-insular acinar cells in the rat pancreas. Eur J Cell Biol 36: 263-268

11. Bendayan M (1982) Cell Contacts between endocrine and exocrine cells in the pancreas. Cell Tiss Res 222: 227-230 
12. Chey WY, Shay H and Shuman CR (1963) External pancreatic secretion in diabetes mellitus. Ann Intern Med 59: 812-821

13. Domschke W, Tympner F, Domschke S, Demling L (1975) Exocrine pancreatic function in juvenile diabetics. Digest Dis 20: 309-312

14. Vacca JB, Henhe WJ, Knight WA (1964) The exocrine pancreas in diabetes mellitus. Ann Intern Med 61: 242-247

15. Adler G, Kern HF (1975) Regulation of exocrine pancreatic secretory process by insulin in vivo. Horm Metab Res 7:290-296

16. Ben Abdeljlil A, Palla JC, Desnuelle P (1965) Effect of insulin on pancreatic amylase and chymotrypsinogen. Biochem Biophys Res Commun 18:71-75

17. Korc M, Owerbach D, Quinto C, Rutter WJ (1981) Pancreatic isletacinar cell interaction: amylase messenger RNA levels are determined by insulin. Science 213:351-353

18. Söling HD, Unger KO (1972) The role of insulin in the regulation of amylase synthesis in the rat pancreas. Eur $\mathbf{J}$ Clin Invest 2: 199-212

19. Bendayan M, Ito S, Manocchio I (1982) Alterations of exocrine pancreatic enzymes in virus-induced diabetic cattle as revealed by immunohistochemistry. Diabetologia 23: 65-68

20. Bendayan M, Nanci A, Herbener G, Grégoire S, Duhr MA (1986) A review on the study of protein secretion applying the protein $A$ gold immunocytochemical approach. Am J Anat 175: 379-400

21. Bendayan M, Roth J, Perrelet A, Orci L (1980) Quantitative immunocytochemical localization of pancreatic secretory proteins in subcellular compartments of the rat acinar cell. J Histochem Cytochem 28: 149-160

22. Bendayan M (1984) Protein A-gold electron microscopic immunocytochemistry: methods, applications and limitations. J Electron Mecrosc Tech 1:243-270
23. Mongeau R, Couture Y, Dunnigan J, Morisset J (1974) Early dissociation of protein synthesis and amylase secretion following hormonal stimulation of the pancreas. Can J Physiol Pharmacol 52: $198-205$

24. Bernfeld P (1955) Amylase $\alpha$ and $\beta$. In: Clourek SP and Kaplan NO (eds) Methods of enzymology. Academic Press, New York, pp 149-159

25. Hummel BCW (1959) A modified spectrometric determination of chymotrypsinogen, trypsin and thrombin. Can J Biochem Physiol 37: 1393-1399

26. Mainz BH, Black O, Webster PD (1973) Hormonal control of pancreatic growth. J Clin Invest 52: 2300-2304

27. Volkin E, Cohn WE (1954) Estimation of nucleic acid. Meth Biochem Anal 1: 284-303

28. Bendayan M, Ito S (1978) Immunohistochemistry of enzymes in normal and diabetic rat exocrine pancreas. Experientia 34: 933

29. Bazin R, Lavau M (1979) Diet composition and insulin effects on amylase to lipase ratio in pancreas of diabetic rats. Digestion 19: 386-391

Received: 5 March 1986

and in revised form: 18 July 1986

Dr. Moïse Bendayan

Department of Anatomy

Faculty of Medicine

University of Montreal

C.P. 6128 , Succ. A

Montreal (Quebec) H3C 3J7

Canada 